\title{
現代日本の建築家による屋上庭園形式をもつ住宅の設計意図 \\ DESIGN THEME IN HOUSES WITH ROOF GARDEN \\ BY CONTEMPORARY JAPANESE ARCHITECTS
}

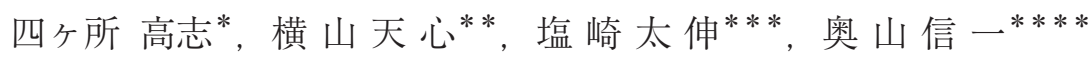 \\ Takashi SHIKASHO, Tenshin YOKOYAMA, Taishin SHIOZAKI \\ and Shin-ichi OKUYAMA
}

\begin{abstract}
This report aims to illustrate how Japanese architects extrapolated a design theme from roof garden model through analyzing text and actual composition of contemporary Japanese houses with such model as it appeared in architectural publications. Initially, two aspects of the roof garden concept were extracted from explanatory text by architect themselves, and each scheme was then subjected to a "KJ-method" analysis (originated by KAWAKITA Jiro); one is the architect's intention in adopting roof garden, the other is the architect's distinct view of the spatial character on roof garden. Secondly, the actual composition of each house was assessed with regard to vertical and horizontal positioning of the roof garden. Finally, the mediation between each architect's thinking and the final composition has been plotted in terms of this dual classification.
\end{abstract}

Keywords : roof garden, spatial form, residential design theory, contemporary Japanese architects, KJ method 屋上庭園, 空間形式, 住宅設計論, 現代日本の建築家, KJ 法

1. 序

\section{1. 研究の背景と目的}

建築の屋根面を屋内と同等に活動可能な領域として空間化する屋 上庭園は、ル・コルビュジエが提唱した「新しい建築の 5 つの要点」注 11 のひとつとして知られており、建築による占有から大地を解放する ピロティとともに、日射や風雨から内部空間を保護する屋根を鉄筋 コンクリートによる水平な面として構成することで、新たな大地を 獲得するという建築理念の提案であった。その建築的実践の代表作 品であるサヴォア邸やユニテ・ダビタシオンを通して示されたよう に、屋上庭園は都市生活のなかで立体的に外部空間を構成する建築 表現として注目を集め、現代に至るまで広く提案されてきた。なか でも屋内外にわたり生活機能がコンパクトに複合する現代日本の独 立住宅においては、建築家注 2)による様々な屋上庭園の実践をみるこ とができる。

たとえば堀口捨己による “岩波邸”では、屋根面全体が一枚の大き な陸屋根による屋上庭園となっており、軒庇やバルコニーによる水 平線や、地上の庭の広がりとともに、水平性を強調した幾何学的な 構成によって建物全体を統合するための主要な要素として機能して いる。また青木淳による “S (エス)”では、地上の中庭と空中に浮か

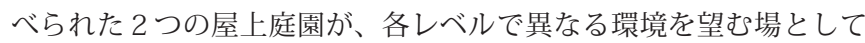
性格づけられ、それらを一挙に貫く螺旋階段によって立体的な回遊 性が実現されている。前者では、隣接する森への眺望によって生活の 快適性を向上させるとともに、広い敷地に建つ邸宅でありながらも都市 住宅のプロトタイプを提案するものとして、後者では、環境要素との対 応や空間体験の豊かさと建築の空間構成とを直結させる方法として屋上 庭園が導大されており、日本の住宅における屋上庭園は、ル・コルビュ ジエによる屋上庭園を基点にしながらも、設計のコンセプトの内容 と連関して様々なかたちで展開してきたと考えられる。

本論では建物の屋根面において、その上部が活動可能な領域とし て構成される空間形式を屋上庭園形式と定義し注3)、現代日本の建築 家による屋上庭園形式をもつ住宅作品を対象に、設計者によって著 された設計論の内容と、実際の作品における屋上庭園形式の特徵と の関連性を検討することで、現代の住宅設計において屋上庭園形式 をもちいる根拠としての建築家の設計意図の枠組みを明らかにする ことを目的としている注4) 注5)。

資料の範囲としては、日本の社会構造が大きく転換した第 2 次世 界大戦以降を現代とし、特に戦後日本の住宅環境の整備や質的向上 を目的に建築に関する各種法制度注 6) が策定された 1950 年以降か

\footnotetext{
本論文は 2002 年度建築学会大会学術講演会で発表されたものを修正してまとめたものである。

福岡大学工学部建築学科 助教・博士 (工学)

** 富山大学芸術文化学部 講師·博士 (工学)

*** 東京工業大学大学院建築学専攻 助教·博士 (工学)

**** 東京工業大学大学院建築学専攻 教授·博士 (工学)

Assist. Prof., Dept. of Architecture, Fukuoka University, Dr.Eng.

Assoc. Prof., Faculty of Art and Design, University of Toyama, Dr.Eng.

Assist. Prof., Dept. of Architecture and Building Engineering, Tokyo Tech., Dr.Eng.

Prof., Dept. of Architecture and Building Engineering, Tokyo Tech., Dr.Eng.
} 
ら 2010 年までを対象期間としている。この間、長期に渡り刊行さ れてきた建築専門誌である「新建築」誌、「新建築住宅特集」誌に掲 載された住宅の作品解説文から屋上庭園形式をもちいた意図が明確 に読み取れる 181 作品を対象に、229 の設計意図を抽出し資料とし た。個々の住宅作品の設計における時代背景や、立地環境などといっ たコンテクストは様々であるが、本論は、数多くの資料を横断的に 比較することで、そうした作品の個別性を越えて、屋上庭園形式を もつ住宅の設計意図の意味の構造を、総体的・相対的に検討するも のである。本論で得られた結果は、ここでの資料の範囲に限定され るものであり、住宅設計一般の問題として敷衍化することはできな いが、屋上庭園形式という空間形式に固有の設計意図の枠組みを顕 在化できる点にこの研究の意義があると考えられる。

\section{2. 既往研究及び本研究の意義}

屋上庭園形式をもつ住宅に関する近年の研究には、まず特定の建 築家の作品を対象としたものとして、千代によるル・コルビュジエ の屋上庭園の概念に関する研究注 7$)$ や森國、朽木、前田によるル・ コルビュジエのラ・ロッシュ/ジャンヌレ邸における屋上庭園に関 する研究注8) が挙げられる。前者は、ル・コルビュジエの全作品にお ける庭園類型の通時的変遷から屋上庭園における『野生性』の概念 を考察するものであり、後者は構想段階から最終案までの平面構成 の変遷からラ・ロッシュ/ジャンヌレ邸における屋上庭園の意味を 論じるものである。これらは新たな建築表現として屋上庭園を提唱 した建築家ル・コルビュジエを、作家論・作品論的な観点から評価・ 考察するものとして成果を上げている。また、広く現代の建築を対 象に屋上庭園形式を取り上げた研究としては、江連、安森による屋 上緑化された都市型住宅作品における外形構成に関する研究注 9$)$ や、 寺内、千葉らによる高密度都市部における屋上緑化可能建築の分布 に関する研究注 10) が挙げられる。これらは、屋根を緑化した屋上庭 園形式をもつ建築を空間構成論として考察するものであり、緑地を 確保し難い都市環境や、地球環境への配慮といった今日的な社会背 景との関係から建築を捉える枠組みを示すものとして評価できる。

これらに対して本論は、数多くの建築家の言説を資料として屋上

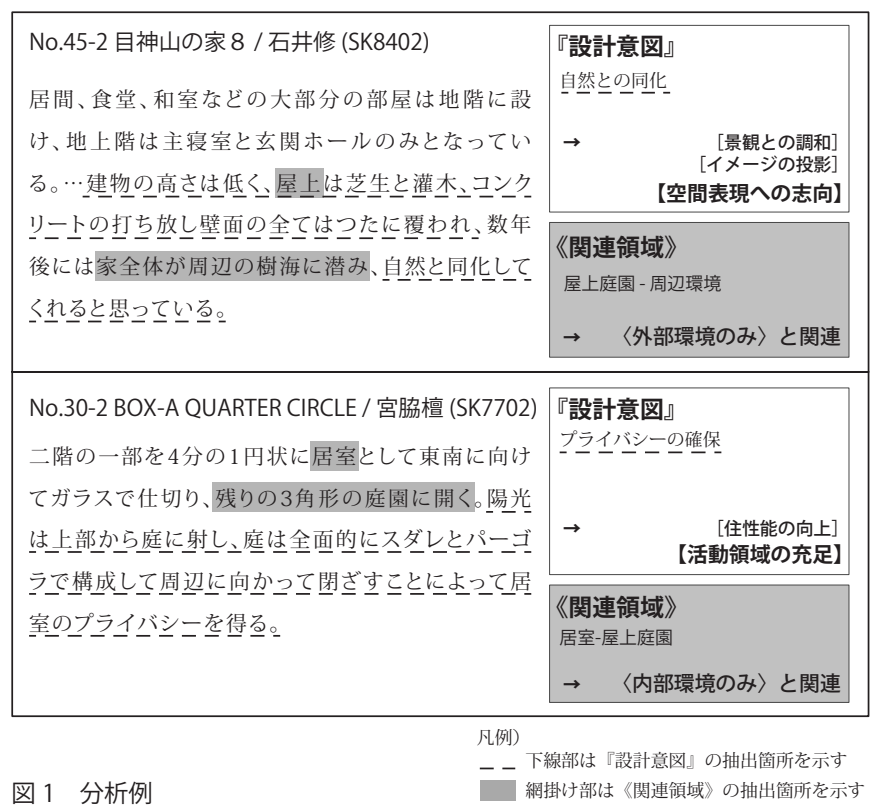

庭園形式をもつ住宅の設計意図を検討することで、現代社会の住宅 に潜在している空間的な枠組みを考察するものである注 11)。

\section{3. 本研究の概要}

本論の概要を述べると、 1 章序論に続き 2 章では、資料とした屋 上庭園形式をもつ住宅の設計論を相互に比較することで、屋上庭 園形式をもちいた意図として明確に読み取れる箇所を抽出し、その 意味内容 (『設計意図』注 12$)$ ) を検討する。例えば、図 1 の分析例 No.45-2 では「建物の高さは低く、屋上は芝生と灌木、コンクリート 打放しの壁面の全てはつたに覆われ…自然と同化してくれると思っ ている。といった箇所から、屋上庭園形式によって周囲の自然環境 がつくる景観に調和する住宅を提案しようとする『設計意図』を読 み取ることができる。一方、分析例 No.30-2 では「…庭は全面的に スダレとパーゴラで構成して周辺に向かって閉ざすことによって居 室のプライバシーを得る」といった箇所から、周辺環境からのプラ イバシーを確保しょうとする『設計意図』を読み取ることができる。 またこのような『設計意図』を構想するにあたり、前者では「…家 全体が周辺の樹海に潜多…（45-2）注 12)」とあるように、屋上庭園を 周辺の外部領域との関連の中に位置づけており、後者では「二階の 一部を 4 分の 1 円状に居室として東南に向けてガラスで仕切り、残 りの三角形の庭園に開く（30-2）」とあるように、居室などの住宅の 内部領域との関連の中に位置づけていることがわかる。このように、 屋上庭園形式をもちいる際に、その『設計意図』が内外のどのよう な領域との関連のなかで示されるかといった内容は、建築家の『設 計意図』の領域的な枠組みを検討する上で重要なものと考えられる。 そこで、これらを屋上庭園形式をもちいた『設計意図』の《関連領 域》注 12) として抽出し、『設計意図』の内容との関係性を検討する。 さらに 3 章では、屋上庭園形式が住宅の屋根面のどこに位置してい るかといった構成パタンを、屋上庭園形式の断面的配置、および平 面的配置の 2 つ水準から整理した上で、それらと『設計意図』及 び《関連領域》との関係を総合的に検討・考察し、4 章で結論を述べる。

\section{2. 屋上庭園形式をもつ住宅の設計意図}

\section{1 . 設計意図の内容}

前述した方法によって抽出した屋上庭園形式をもつ住宅の『設計 意図』を、 $\mathrm{KJ}$ 法注 13) に基づいて相互に比較検討した。その結果、そ れらは［景観との調和］注12）［イメージの投影］［生活空間の拡張］[空 間の構成的操作］［敷地の有効利用］［住性能の向上］の 6 つの意味 のまとまりとして捉えることができた（図 2)。

［景観との調和］は、屋上庭園形式によって住宅と周囲の景観との 一体的な関係の構築を位置づけるものであり、山岳風景などとの対 応について述べられる〔自然との関係〕注12) と、街並みなどとの対 応について述べられる[都市との関係〕から捉えることができる。〔自 然との関係」には、緑化された屋上によって、周囲の自然と住宅と を同化させようとするもの（No.29, 45-2, 105, 164）注12)、これに対 して人工的に制御された庭としての屋上によって、周囲の自然を顕 在化しょうとするもの（No.40-2, 51, 85, 99, 101-2, 110-2, 154）な どがみられ、〔都市との関係〕には、屋上に周囲から視認できる植栽 を施すことで、街並みへの寄与を図るもの（No.10, 14, 23, 143, 147, 179)、屋上を都市の断片として構成することで、住宅に都市性を内 包させようとするもの（No.52, 72, 86-1, 89-2）などがみられた。 
[イメージの投影］は、屋上庭園形式という独特な空間構成によっ て、建築家が自身の空間イメージの実現を試みたと位置づけられる ものであり、屋上庭園形式を実体化した際に立ち現れる空間の状態 や性質などの抽象的なイメージに関する〔空間の現象的性質〕注 12) と、建築ではない何らかの具体的な事物への類推的イメージに関す る〔アナロジー〕から大きく捉えることができる。〔空間の現象的性 質】には、屋上庭園形式によって建築の輪郭を曖昧化し、建築らし さを消去しょうとするもの（No.58-2）注 12)、床の水平性やその積層 による垂直性といった異なる空間の性質を同時に顕在化しょうとす るもの（No.46, 113-1, 136-2）などがみられ、〔アナロジー〕には、 異国の都市や集落へのイメージを屋上庭園形式に重ねて表現するも の（No.41-2,115-2）、空中に浮かぶ楽園として屋上庭園形式をイメー ジするもの (No.87-2)、船の甲板をイメージするもの (No.81-2, 160)、 屋上を緑化することで、その下の内部空間を地下空間としてイメー ジするもの（No.17）などがみられた。また［イメージの投影］の 中では、〔空間の現象的性質〕〔アナロジー〕に含まれない内容とし て、近代建築のボキャブラリーとしての屋上庭園形式をイメージす るもの（No.81-1, 107, 132）や、都市住居のプロトタイプとして屋 上庭園形式をイメージするもの（No.1-2, 30-1, 49, 58-1, 66-2, 87-1, 142-1,167）がみられた。
[空間の構成的操作］は、屋上庭園形式を住宅の空間を構成するた めの方法との関係から論じるものであり、さまざまな用途をもつ住 宅の空間全体を緾める方法として論じる〔全体と部分の関係〕注 12) と、住宅全体の中で局所的な関係をつくるための方法として論じる 〔部分と部分の関係〕から捉えることができる。〔全体と部分の関係〕 には、住宅の諸室を相互に連結する中心的な場として屋上庭園形式 を位置づけるもの（No.47-1,90）注 12)、地上の庭などと接続し動線 的な回遊性の獲得を試みるもの（No.16, 41-1, 86-2, 96, 102, 115-1, 118, 125-1, 145, 156-1, 157, 168, 169, 180-2)、これと同様に他の 外部空間との視覚的なシークエンスの獲得を試みるもの（No.20-2, 44-1, 57, 69, 70, 84, 112-1, 124-3, 129, 150, 173)、隣地や周辺環 境と住空間との緩衝空間として屋上庭園形式を位置づけるもの(No.9, 42,78-2, 95, 119-1，156-2,172）などがみられ、〔部分と部分の関係] には、フロアごとに異なる性格・機能を充て、屋上を含め等価な領 域が積層された結果として住空間を構成するもの（No.36, 63, 110-1, 121，135，140)、居室同士、あるいは居室と周辺環境など、場と場 を断片的に繋ぐための接点領域として屋上庭園形式を位置づけるも の（No.108-1, 133, 151-2, 175, 181-2）などがみられた。

[生活空間の拡張］は、屋上庭園形式によって得られる生活空間の 便宜性について論じるものであり、限られた建築面積の中に計画的

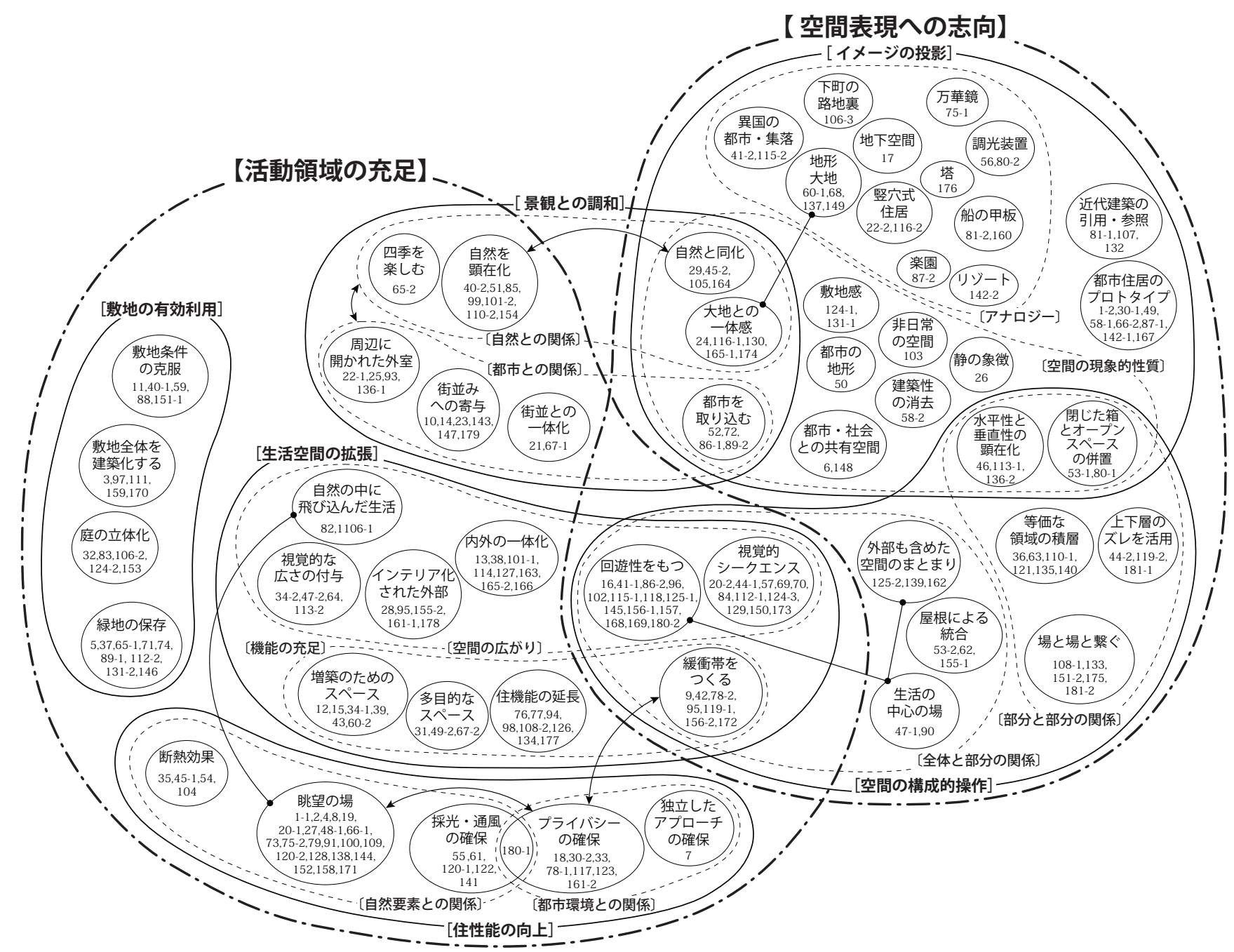

図 2 屋上庭園形式をもつ住宅の設計意図 図 2 注) 各々の意味内容の下に記した数字は資料とした言説の通し番号である。ひとつの資料より複数の設計意図が抽出されたものはさらに添番号をつ けている。また、図中において棒線により示したものは意味内容のつながりが強いもので、矢印で示したものは意味内容が背反するものである。 
な合理が求められる現代社会の住宅において、必ずしも充足されな い機能を補うものとして論じられる〔機能の充足〕注 12$)$ と、屋上庭 園形式により獲得される空間の領域的広がりを、体験的に高めるも のとして論じられる〔空間の広がり〕から捉えることができる。〔機 能の充足]には、住宅内の活動や機能を屋外へと延長するための場 として屋上庭園形式を位置づけるもの（No.76, 77, 94, 98, 108-2, 126，134，177）注12）これに対し、屋上庭園形式に明確な機能を与 えず、様々な使われ方を許容する多目的な空間として位置づけるも の（No.31，49-2, 67-2)、またこれらのように住機能を前提とするの ではなく、家族構成の変化などに伴う将来的な増改築への拡張性に 配慮するもの（No.12, 15, 34-1, 39, 43, 60-2）などがみられ、〔空間 の広がり」には、居室に視覚的な広さを付与するものとして屋上庭園 形式を位置づけるもの（No.34-2, 47-2, 64, 113-2）、半屋外空間とし ての屋上庭園形式を居室に併設することで、屋内外の一体化した空 間をつくろうとするもの（No.13, 38, 101-1, 114, 127, 163, 165-2, 166）などがみられた。

[敷地の有効利用］は、敷地全体を効率的に活用するための手法と して屋上庭園形式を位置づけるものである。それらには、住宅を建 築することで失われる緑地を保持するために屋上庭園形式をもちい るもの（No.5, 37, 65-1, 71, 74, 89-1, 112-2, 131-2, 146）注12)、狭 小敷地や特異な敷地形状などの不利な敷地条件においても積極的に 庭を獲得しようとするもの（No.11, 40-1, 59, 88, 151-1）、庭と建築 の境目を無くし、敷地全体を建築化しようとするもの（No.3, 97, 111, 159，170）、地上から屋上まで庭を立体的に形成するもの（No.32,83, 106-2, 124-2, 153）などがみられた。

[住性能の向上］は、屋上庭園形式をもちいることで得られる生活 の快適性について論じるものであり、自然環境に対する快適性を求 める〔自然要素との関係〕注 12) と、都市的な環境に対する快適性を 求める〔都市環境との関係〕とから捉えることができる。〔自然要素 との関係りには、周辺の自然環境への眺望を得ようとするもの(No.1-1, 2, 4, 8, 19, 20-1, 27, 48-1, 66-1, 73, 75-2, 79, 91, 100, 109, 120-2, $128,138,144,152,158,171)$ 注 12)、採光や通風を確保するために 屋外空間を立体的に構成するなかで、積極的に屋上庭園形式を導入 するもの（No.55, 61, 120-1, 122, 141, 180-1）、屋上を緑化するこ
とで屋根面に断熱効果を得ようとするもの（No.35，45-1，54，104） などがみられ、〔都市環境との関係〕には、庭を地上から持ち上げる ことで住居のプライバシーを確保しょうとするもの(No.18, 30-2, 33, 78-1, 117, 123, 161-2,180-1）などがみられた。

ここで屋上庭園形式が、建築の屋根面を屋内と同等な領域として 空間化するものでもあることを勘案し『設計意図』の内容を概観す ると、それらは、屋上庭園形式を住まい手の生活や立地環境との関 係から論じ、社会的側面における住宅の機能性を補完する領域とし て位置づける【活動領域の充足】注 12) と、そうした活動領域として だけでなく、屋上庭園形式を自身の空間表現を志向する対象として 積極的に位置づける【空間表現への志向】といった『設計意図』に 関する 2 つ大枠から捉えることができる（図 2)。本論で検討して いる資料の範囲においてではあるが、[敷地の有効利用］[住性能の 向上］[生活空間の拡張］は【活動領域の充足】に、[イメージの投影] [空間の構成的操作］は【空間表現への志向】に包摂される内容とし て位置づくのに対し、[景観との調和］は双方にまたがる内容である ことが分かる。また、[生活空間の拡張］と［空間の構成的操作］の 重なりに含まれるものは【活動領域の充足】【空間表現への志向】の 双方の性格をもつ内容として位置づけられた。

\section{2. 屋上庭園形式の設計意図と関連領域}

ここでは、前節で整理した屋上庭園形式の『設計意図』を実現す る上で、屋上庭園形式を屋内外のどのような領域との関連の中に認 識しているかといった《関連領域》について検討する。全資料から 屋上庭園形式との関連が明確に読み取れる箇所を抽出し注 ${ }^{14}$ ) (図 3 具 体例の網掛け部)、それらを住宅内の居室など内部領域を指すか、敷 地内の外部空間や周辺環境など外部領域を指すかに分類した。まず、 $「 \cdots$ 予測される家族構成の変化に対して…両方の寝室の庭は透明な函 をそれぞれにもつことができるような広さをもっている。(No.12)」 のように〈内部領域のみ〉注 12) との関連を述べるもの、「老人だけの 庭や、イタズラ盛りの孫たちの庭、長男夫婦の夏の夜の星空の居間 というか屋上庭園などが、それぞれを結んで花期には美しい花をつ ける、サツキとツツジの群落がある。(No.32)」のように〈外部領域 のみ〉との関連を述べるものを位置づけることができる。さらにこ れらの組合せとして、「この住宅の空間のまとまりを都市環境までは

\begin{tabular}{|c|c|c|}
\hline \multicolumn{3}{|c|}{ 《関連 領 域》 } \\
\hline $\begin{array}{l}\text { 〈内部領域のみ } \\
\text { 居室などの屋内空間 } \\
\text { のみと関連性をもつもの }\end{array}$ & $\pi$ & 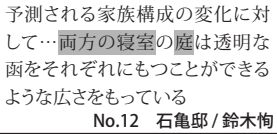 \\
\hline
\end{tabular}

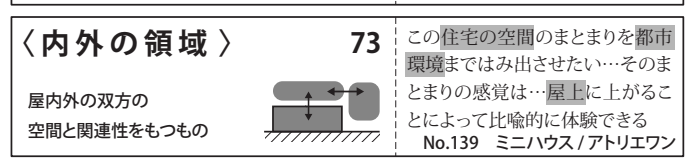

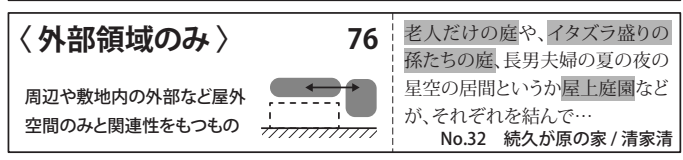

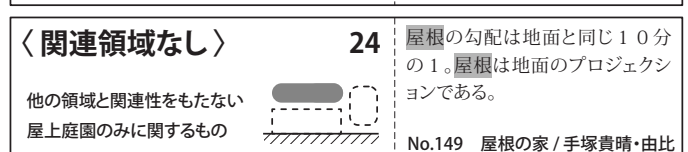

図 3 屋上庭園形式の関連領域と設計意図
【空間表現への志向】【活動領域の充足】
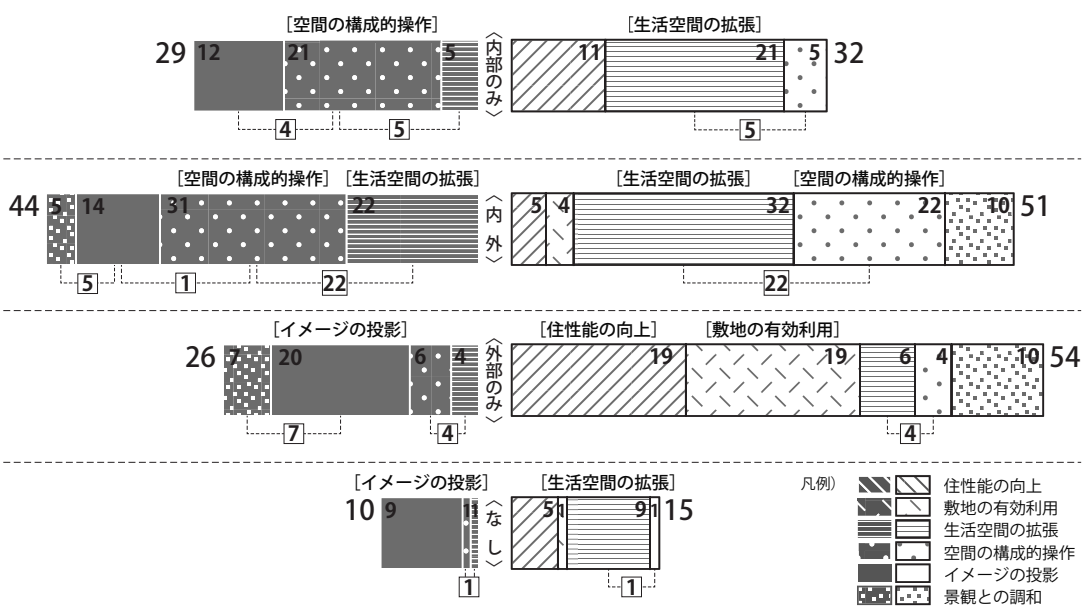

図 3 注) グラフ横の数字は該当する資料総数を示しており、グラフ中の数字は『設計意図』の内訳を示す。ただし、複数の『設 計意図』を横断する資料は重複して集計しているためグラフ横の総数とは一致しない。内訳はあくまで『設計意図』単位で集 計した際の割合を示している。また、重複する資料については、横断する『設計意図』同士を点線で結び、その数を示した。 
み出させたいと思った。…そのまとまりの感覚は…屋上に上がるこ とといった境界を越える体験の反復によって、身体的なレベルでも 比喻的に体験できると思う。(No.139)」のように内部領域と外部領 域の双方との関連を同時に述べるもの（〈内外の領域〉）、「屋根の勾 配は地面と同じ 10 分の 1 。屋根は地面のプロジェクションである。 (No.149)」のようにどちらの領域とも関連が述べられないもの（〈関 連領域なし〉）を位置づけることができた（図 3 左）。

上記で見出した 4 つの《関連領域》ごとに『設計意図』の大枠と の対応、および具体的な『設計意図』の内訳を割合として図示した ものが図 3 右の棒グラフである。まず『設計意図』の大枠との対応 において、〈内部領域のみ〉〈内外の領域〉ではそれぞれ【空間表現 への志向】【活動領域の充足】の割合が同程度であるのに対し、〈外 部領域のみ〉では【活動領域の充足】に偏りがみられた。

さらに内訳として示した『設計意図』の内容を含めて《関連領域》 との対応を比較する。『設計意図』の大枠との対応に偏りがみられな かった〈内部領域のみ〉〈内外の領域〉に注目すると、まず〈内部領 域のみ〉では、空間表現への志向】において [空間の構成的操作］が、 【活動領域の充足】において [生活空間の拡張] が大半を占めている のに対し、〈内外の領域〉では、空間表現への志向】活動領域の充足】 の双方において［空間の構成的操作］［生活空間の拡張］が同程度み られ、特にこれら 2 つ内容を併せもつ資料が多くみられた（空間 表現への志向】においては 22/44 資料、【活動領域の充足】におい ては 22/51 資料)。このことは、屋上庭園形式によって生活空間を 拡張しようとする意図と、住宅の空間構成を志向する意図とがそれ ぞれ単独で構想される際には、住宅の内部空間との一義的な関係の 中に屋上庭園形式が認識されるのに対し、双方を同時に意図する際 には、住宅の内部空間から外部環境までと連続した領域的広がりの 中に屋上庭園形式が認識されることを示しており、屋上庭園形式を 屋内外にわたる領域的な性格の多様性の中に捉えることで、『設計意 図』を構想する際の建築家の思考に多面的な視点が生じることを示 唆するものである。また、〈外部領域のみ〉と【活動領域の充足】の 対応においては、[住性能の向上］[敷地の有効利用］が多くみられた。 このことは、現代の住環境においては周辺からの引きや十分な広さ の庭を確保することが困難なため、外部環境との関係の中で形成さ れる住宅の機能性（居住性能や敷地の有用性）が不足しており、こ れを補完する有効な手段として屋上庭園形式が捉えられていること を示すと考えられる。

\section{3. 屋上庭園形式の構成パタンと設計意図・関連領域}

ここまで、屋上庭園形式をもちいた建築家の思考を大きく『設計 意図』と《関連領域》の 2 つ側面から検討してきた。屋上庭園が 「地上から独立した大地」として構成されるものであることを鑑みる と、屋上庭園が住宅全体のなかで断面的、および平面的にどのよう に配置しているかは、屋上庭園形式をもちいた建築家の思考の空間 的な枠組みを考察する上で重要な指標になると考えられる。そこで 本章では、まず、作品発表時の図面や写真を資料とし、実体化され た屋上庭園形式の住宅の構成パタンを、屋上庭園の断面的配置、お よびそれら断面的配置ごとに特徵付けられる屋上庭園の平面的配置 から分類し（図 4 )、さらに、それらと《関連領域》および『設計意図』 との対応を検討する。

\section{1. 屋上庭園形式の構成パタン}

屋上庭園の断面的配置については、屋上庭園が \{単層\} 注 12$)$ であるか、 \{複層\}にわたって位置するかに大別し注 ${ }^{15)} 、\{$ 単層\}については屋上 庭園が最上層に位置する \{単層 (上) $\}$ と中間層に位置する $\{$ 単層 (中) $\}$ に分類した（図 4 左）。

次に、屋上庭園の平面的配置を断面的配置の項目ごとに検討した。 断面的配置が \{単層 (上) \} のものは、屋上庭園が屋根面全体に及ぶか、 部分に留まるかから捉え注 16 、 、弾層（中）～のものは屋上庭園と同レ ベルに存在する内部空間との平面的な位相関係を考慮し、居室を包 含するもの、居室と並置するもの、居室に包含されるものから捉え た注 17)（図 4 中央）。以上の屋上庭園の断面的配置、およびそれに基 づく平面的配置から、資料とした住宅における屋上庭園形式につい て全面型、部分型、居室包囲型、居室並置型、中庭型、段床型の 6 つの構成パタンを位置づけた（図 4 右）。

\section{2. 屋上庭園形式の構成パタンと設計意図・関連領域}

まず上記の構成パタンと『設計意図』の対応関係を比較した結果、 屋上庭園の断面的配置が \{単層 (上) \} の全面型、部分型では [イメー ジの投影］や［住性能の向上］が相対的に多くみられるのに対し、弾 層（中）？の居室平地型、中庭型では [生活空間の拡張］や［空間の 構成的操作］が多くみられた（8頁付表）。以下では、これらの数的 傾向と各構成パタンの該当資料数の多少を踏まえ注 ${ }^{18)}$ 、全面型、居室 並置型、中庭型の3つのパタンについて『設計意図』および《関連領域》 との関係を詳述する。それぞれの構成パタンごとに《関連領域》の 4 項目を頂点として該当資料数をグラフ化し（太線）、さらにその内 訳となる『設計意図』の大枠の該当数をグラフ化 (【空間表現への志向】 は網掛け、【活動領域の充足】は細線) したのが図 5 である。

まず全面型では〈外部領域のみ〉に偏りがみられ、特に【活動領 域の充足】に関する『設計意図』が多くみられた。なかでも、「屋上

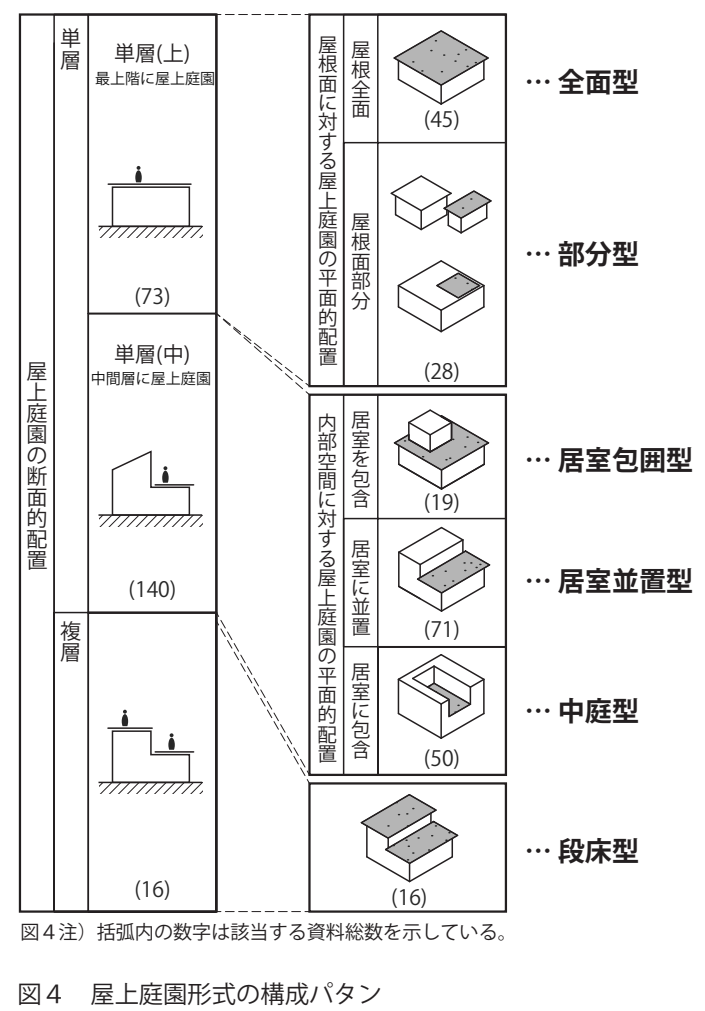




\section{全面型 45}

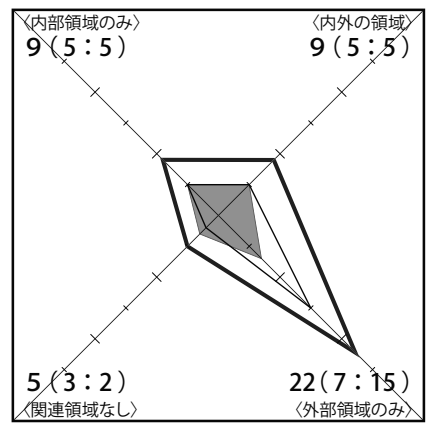

居室並置型 71

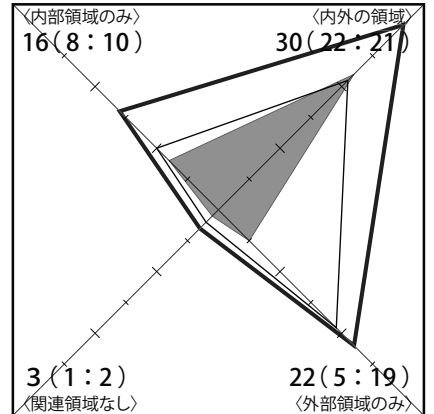

\section{中庭型 50}

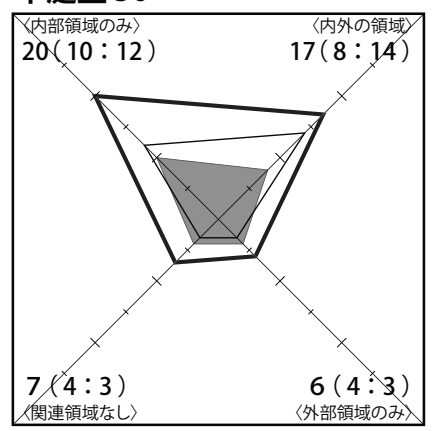

図 5 注)

図中の数字は、凡例で示すように各項目の該 当数を示している。ただし、複数の『設計意図』 を横断する資料については重複して集計して いるため、内訳数の和と総数とは一致しない。 図 5 凡例)

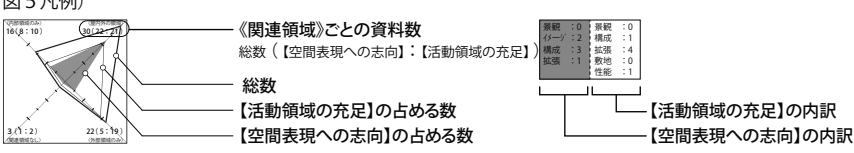

図 5 屋上庭園形式の構成パタンと設計意図・関連領域
は空に接した別世界であり、細々とした地上の光景から離れて、天 空に開け、遠い東京の住宅地のスカイラインを見晴らす場所である。 （No.109）」のように、眺望の場をつくることで［住性能の向上］を 図る『設計意図』が内訳として多くみられた（7/15 資料）。このこ とは、住宅の内部空間では得られない外部環境との視覚的な繫がりを 積極的に空間化する方法として、屋根面全体を活動可能な領域とし て活用する屋上庭園形式が構想される傾向にあることを示すと考え られる。

次に居室並置型では、〈内部領域のみ〉〈内外の領域〉〈外部領域の み〉がそれぞれ多くみられる中で、特に〈内外の領域〉に偏りがみ られた。〈内外の領域〉における『設計意図』の内容を比較すると、【空 間表現への志向】と【活動領域の充足】が同程度みられ、その内訳 として [空間の構成的操作］［生活空間の拡張］の双方の内容を併せ もつ資料が多い（13/30 資料）。これらは、「屋上の芝とデッキもア ウトドアパーティー会場となり、ブリッジとベランダを経由して両 家の 1 階へと続く、立体的で回遊性のあるトポロジカルな空間を形 成している。(No.115-2)」や「二階の床レベルは、ルーフガーデン より $70 \mathrm{~cm}$ ほど低く、空からの視線はルーフガーデンの樹木から空 へと連続する。(No.20-2)」のように、住宅の内外に動線的な回遊性 や視覚的なシークエンスを形成しようとする内容のものである。こ のことは、住宅の内外を横断した空間体験を特異な空間構成によっ て表現するための手段として、住宅の内部空間と屋上庭園、さらに はその先の外部環境までもが等価な関係で並置された屋上庭園形式 が構想される傾向にあることを示すと考えられる。

中庭型では、〈内部領域のみ〉〈内外の領域〉が多くみられた。こ れらの『設計意図』の内容に注目すると、大枠およびその内訳の双 方において特徴的な偏りがみられない。これは、住宅の内部空間に 囲われた屋上庭園形式がコートヤードハウスという別の空間形式を 兼ねたものであり、周囲の外部環境から独立した外部空間を形成す るとともに、2つの空間形式が融合した複合的な性格をもつため、 住宅を建築の自律した系として構想することを可能にし、さまざま な『設計意図』が展開される傾向にあることを示すと推察される。

\section{4. 結}

本論は、屋上庭園形式をもつ住宅の設計論を作品の実体的側面を 含めて総体的に分析することで、屋上庭園形式という特徵的な空間 形式と連関した建築家の設計論の内容の広がりとその枠組みを明ら かにするものであった。まず屋上庭園形式をもちいた根拠としての 建築家の設計意四の内容を比較検討し、6つの意味のまとまりとし て捉えた。またそれらの設計意図に関して、生活機能を充足するた めの領域として提案されるものか、建築家自身の空間表現を志向す

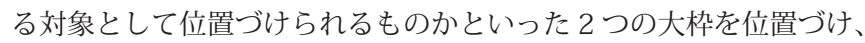
それらと具体的な設計意図の内容との関係を示した。次にそうした 設計意図を構想する上で、屋上庭園形式を住宅の内部と外部のどち らの領域との関連の中に認識しているかといった関連領域を整理し、 それらと設計意図との関係を比較することで、外部領域のみと関連 づけられる屋上庭園形式が、現代の住宅に不足する生活の機能性を 満たすための活動領域として展開されるのに対し、内部領域あるい は内外双方の領域と関連づけられる屋上庭園形式が、活動領域を充 足するものとしてだけでなく、空間性を表現するための思考対象と 
しても位置づけられる傾向にあることを示した。さらに、このよう な屋上庭園形式をもちいた建築家の思考の空間的な枠組みを検討す るため、実際の作品における屋上庭園の断面的・平面的配置から屋 上庭園形式の構成パタンを導き、それらと設計意図および関連領域 との対応を検討した。その結果、屋根面全体を屋上庭園にする空間 形式、屋上庭園と居室を並置する空間形式、屋上庭園を居室で囲う 中庭型の空間形式が、それぞれ、外部環境との関係の中で住宅の機 能性を補完するもの、屋内外に連続した生活の豊かさを空間の構成 によって実現しようと試みるもの、外部環境への閉鎖性とともに建 築の自律したモデルとして様々な思考が展開されるものとして構想 される傾向にあることを示した。

本論でみられた屋上庭園形式をもつ住宅の設計論の内容の広がり や、それらと実際の作品の空間形式との関連性は、空間形式を思考 の起点にして建築設計を実践していくことの可能性を示すものであ ると言える。ここで得られた空間的な枠組みを伴った建築家の思考 の総体的・相対的な広がりは、屋上庭園形式という特定の空間形式 に関する範囲のものではあるが、今後の建築家の創作活動において ひとつの指針になると考える。

\section{注}

注 1) ル・コルビュジエの提唱した「新しい建築の 5 つの要点」は、日本で は一般的に「近代建築の 5 原則」として知られており、「ピロティ」「屋 上庭園」「自由な立面」「自由な平面」「独立骨組みによる水平連続空」 の 5 つの建築言語からなる。この内、「屋上庭園」とは、建物の屋根 を陸屋根とし、人工的な地盤とすることで、その上部を新たな大地と する形式を指す言葉として知られている（参考文献 1，2，3）。

注 2) ここでは、主に建築作品あるいは建築論をジャーナリズムに発表する ことによって、建築の表現活動としている建築の設計者をさして建築 家とよんでいる。その上で、建築家の表現活動を建築の創作活動と言 説活動のふたつで大きくは構成されるとしている。

注 3）注 1 における屋上庭園の定義に加え、屋根面が陸屋根でなく勾配をも つものであっても、その上部が活動可能な領域として構成されている ものや、屋上庭園の断面的な位置が建物の最上層でなくとも、その下 部に内部空間を有するものは、屋上庭園形式をもつ住宅としている。

注 4) 本論では、建築家の著した設計論と実際の住宅作品の関係、つまり「言 葉」と「実体」との関係を分析しているが、このような方法は着想段 階から実際の設計までの建築家の論理的な一貫性を明らかにしようと するものではない。現代の屋上庭園形式の住宅に潜在している空間的 な枠組みを、個々の設計意図の集積として現れる社会的な枠組みとの 関係から見出そうとするものである。

注 5) ここでの分析、扔よび検討内容は、拙稿（参考文献 4，5）を修正し、 発展させたものである。

注 6) 1950 年、戦前からの建築関係資材統制や、住宅制限が解除されると ともに、建築および住宅の質的向上を目的として建築基準法、建築士 法、住宅金融公庫法が公布された。

注 7) 参考文献 6)

注 8) 参考文献 7)

注 9) 参考文献 8)

注 10) 参考文献 9), 10)

注 11) このような特徴的な空間形式をもつ住宅の設計論に関して、コア型平 面形式、一室空間形式、およびピロティ形式をもつ住宅作品について は、それぞれ既報（参考文献 11,12,13）で取り上げており、各空間 形式を用いた現代の建築家の思考の枠組みを報告している。

注12) 本論では下記のように括弧を使い分けている。

$『 』$ : 屋上庭園形式をもつ住宅の設計意図の意味内容を示す際に『設 計意図』と記す。

【 】：『設計意図』のカテゴリー、第 1 水準。

[ ］：『設計意図』のカテゴリー、第 2 水準。

〔〕：『設計意図』のカテゴリー、第 3 水準。
《》: 地上から独立した庭としての屋上庭園をもちいる上で、屋上庭 園形式を屋内外どちらの領域との関連性のなかに認識する事で 『設計意図』の実現を図ったかといった内容を示す際に《関連 領域》と記す。

\langle\rangle$:$ 《関連領域》のカテゴリー。

$\{\quad\}$ : 屋上庭園形式をもつ住宅の実体的側面に関するカテゴリー。

（）：資料番号。

注 13) KJ 法とは民族地理学の分野で川喜田二郎によって考案されたものと して知られており、何らかの問題提起から状況把握、そしてそれに対 する解決方法のプロセスまでの一連の方法をいう。ここではそのなか で、ある問題をめぐって問題のあり得る情報を集め、定性的データと し、意味の分かるような全体像とするまでのプロセスを狭義での KJ

別表 資料リスト

\begin{tabular}{|c|c|c|c|c|c|c|}
\hline 瓷䊩料 & 掲載誌 & 作品名 & 設計者 & 凟料 & 掲載誌 & 作品名 \\
\hline \begin{tabular}{|c|}
1 \\
\end{tabular} & SK5801 & 岩波期 & 堀口唅巳 & \begin{tabular}{|l|l}
92 \\
\end{tabular} & \begin{tabular}{|l|}
$J T 9301$ \\
\end{tabular} & 葛飾の住宅 \\
\hline 2 & SK5805 & 崖地に建つ家 & 森京介 & 93 & JT 9302 & 天応の家 \\
\hline 3 & SK5901 & コンクリードロロ听の家 & 田中正美 & 94 & |Јт 9303 & |十坪の塔 \\
\hline 4 & SK5902 & E氏氏郎 & 森京介 & 95 & JT 9305 & NI HOUSE \\
\hline & sk 6408 & 的期 & 堀口捨己 & 96 & JT 9308 & 高根台の家 \\
\hline & SK6501 & すまい & 藤木忠善 & 97 & JT 9308 & TRASS - WALL · HOUSE \\
\hline & SK6601 & 九段の家 & 安藤勝男 & 98 & |Јт 9309 & 三世代の家 \\
\hline 8 & SK6605 & 赤星邸 & 早稲田大学U研究室 & 99 & |JT 9310 & |堺町の家 \\
\hline & SK6701 & 宾戸㿟 & 鈴木恂 & $100 \mid$ & |JT $9310 \mid$ & 价ブルルーフの家 \\
\hline 10 & Sk6801 & S期 & 村田政真 & $101]$ & JT 9311 & 山中湖のガラ \\
\hline 11 & SK6801 & 青山台の家 & 石井修 & 102 & |JT 9401 & 太田さんの家 \\
\hline 12 & SK6804 & 石亀邸 & 鈴木恂 & 103 & JT 9407 & 聖踏桜ヶ丘の家 \\
\hline 13 & SK6805 & ギャラリーのある家 & 竹山実 & 104 & JT 9409 & HOUSE TM \\
\hline 14 & SK6904 & |U氏邸 & 坂倉建築事務所 & [105]. & JT 9410 & SOFT AND HAIRY HOUSE \\
\hline 15 & SK6905 & 続坪井教授の家 & 清家清 & 106 . & JT 9410 & 空の中庭 \\
\hline 16 & SK6909 & ㅊ川郎 & 山下司 & $107 \mid$ & | JT 9412 & ドミノ1995 \\
\hline 17 & $5 \bar{K} 7006$ & GAH 6812 & & 108 . & JT 9501 & くまむ \\
\hline 18 & SK7110 & ブルーボックスハウス & 宮脇檀 & {$[109]$} & JT 9502 & 東大泉の住宅1994 \\
\hline 19 & SK7110 & |山王の家 & デザインシステム & 110 . & |Јт 9503 & 熱海のアトリエ住居 \\
\hline 20 & SK7208 & 南馬込の家 & 小玉祐一郎 & 111 . & JT 9503 & 大塚期 \\
\hline 21 & SK7307 & 吳さんの家 & 坂倉建築研究所 & $\mid 112$ | & | JT 9504 [ & 鹿/台の家 \\
\hline 22 & SK7502 & 天と地の家 & 石井修 & [113] & [JT 9504 [ & 東ヶ丘の家 \\
\hline 23 & SK7508 & 緑段の家 & 竹口 & [114]. & JT 9505 & 東条湖の別荘 \\
\hline 24 & SK7508 & 千里山 & & 115 & JT 9505 & ドムス \\
\hline 25 & SK7508 & 千倉の家 & 内井昭蔵 & $116]$ & JT 9507 & 縄庵 \\
\hline 26 & SK7602 & 段象の家 & 相田武文 & $|117|$ & JT 9507 & 松原の家 \\
\hline 27 & SK7609 & 啮谷邸 & 新田鷹雄 & 118 . & |ЈT 9508 & A HOUSE \\
\hline 28 & SK7702 & 茅ヶ崎の家 & 武者英二研究空 & 119 & |JT 9508 & N HOUSE \\
\hline 29 & SK7702 & |回帰草庵 & 石井修 & $\mid 120$ | & $\mid$ JT $9508 \mid$ & 中目者の家 \\
\hline 30 & SK7702 & BOX- & & [121]. & JT 9511 & $F 4$ \\
\hline 31 & SK7702 & 恋ヶ注 & & 122 & JT 9511 & suzı \\
\hline 32 & SK7708 & 続久が原の家 & |清家清 & 123 & JT 9511 & 住居No1 共生住居 \\
\hline 33 & SK7708 & 五本木の家 & 阿部勤 & 124 . & |ЈT 9602 & 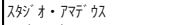 \\
\hline 34 & SK7802 & GOH7603 & 鈴木怕 & 125 & JT 9608 & S (エス ) \\
\hline 35 & SK7808 & 真喜志期 & 真喜志好- & $126]$ & JT 9609 & ドミノ1996 \\
\hline 36 & SK7902 & 樹木希林の家 & |黑川哲郎 & 127 . & JT 9609 & TWIN HOUSE \\
\hline 37 & SK7908 & 目神山 & & |128| & |JT 9612 _ & \\
\hline 38 & SK 8008 & $\mathrm{Y}=-ト ハ 0$ & & 129 & JT 9612 & \\
\hline 39 & SK8008 & 対空間の家 & & 130 & JT 9702 & \\
\hline 40 & SK8101 & 花山第4の住宅 & 篠原一男 & 131 . & |Јт 9703 & 繰り返しヴ オー以のある \\
\hline 41 & SK8208 & 北川さんの家 & 早川邦彦 & 132 . & JT 9706 & まんぼう1997 \\
\hline 42 & SK8211 & 藤井邸 & 山本理顕 & 133 . & |ЈT 9709 & \\
\hline 43 & SK8302 & 狭山の家 & & 134 . & |JT 9801 & 駒場のコート \\
\hline 44 & SK8308 & & & | 135 & JT 9802 & ハウス \\
\hline 45 & SK8402 & & & 136 & JT 9803 & \\
\hline 46 & SK8408 & 吉祥寺の家 & 次郎 & 137 & JT 9805 & POLYPHONY \\
\hline 47 & SK8408 & P.P.P & 渡辺明 & 138 . & JT 9806 & |阪田小屋 \\
\hline 48 & JT 85秋 & 小俣邸 & 山本理䫓 & 139 . & JT 9901 & |ミニハウス \\
\hline 49 & JT 8607 & 島之内の町屋 & 石井修 & 140 . & |ЈT 9903 & 保土ヶ谷の住宅 \\
\hline 50 & JT 8609 & GAZEBO & 山本理顕 & $141]$ & JT 9906 & \\
\hline 51 & JT 8609 & 練馬の住宅 & & 142 . & | JT 9909 & 両国のコート \\
\hline 52 & JT 8609 & 加瀬 & & 143 & |ЈT 9912 & \\
\hline 53 & JT 8609 & 馬込沢の家 & & 144 & JT 0002 & 野火止 \\
\hline 54 & JT 8610 & 光明台の家 & & 145 & J Ј 0003 & 高松ヒルトップハウス \\
\hline 55 & JT 8701 & M-HOUSE & 芦原太郎 & 146 & Jт 0008 & 桜ヶ丘の家 \\
\hline 56 & JT 8701 & 西原の家 & 室伏次郎 & 147 . & Jт 0011 & HOUSE 9 \\
\hline 57 & JT 8707 & & & 148 & JT 0011 & 土佐堀の家 \\
\hline 58 & JT 8708 & 東玉川 & & 149 & JTo 0108 & 偓根の \\
\hline 59 & JT 8710 & M氏の & & 150 . & |Јт 0109 & \\
\hline 60 & JT 8804 & イズ・ブレタ & & 151 & JT 0110 & \\
\hline 61 & JT 8804 & |フィッシュボ & 岡崎恭子 & {$[152]$} & Jт 0111 & 壁のない家 \\
\hline 62 & JT 88 & HAMLE & & 153 . & Jт 0112 & 新緑住 \\
\hline 63 & JT 8808 & 狩場の & 室伏吹 & 154 . & JT 0204 & i-house \\
\hline 64 & JT 8808 & 鎌倉上 & & 155 . & Jт 0303 & \\
\hline 65 & |ЈT 8809 & & & | & JT 0303 & \\
\hline 66 & |ЛT 8809 & ヴィニ & & |157 & JT 0406 & \\
\hline 67 & JT 88 & KE & & 158 & [JT 0411 & \\
\hline 68 & & TFORM & & 159 & JT 0501 & アシタ \\
\hline 69 & & 尾山台の住宅 & & 160 & JT 0512 & 書家の \\
\hline 70 & & o期 & & 161 & |ЈT 0603 & 上志津の家 \\
\hline 71 & JT 8811 & 目白山の家 10 & 石井信 & $162]$ & JT 0607 & \\
\hline 72 & JT 8903 & & 竹中工衫 & 163 . & Jт 0611 & HORIZOI \\
\hline 73 & JT 89 & & & | 164 & JT 0702 & \\
\hline 74 & JT 8909 & 新于里 & & 165 . & JT 0704 & 前橋 \\
\hline 75 & JT 8 & 加价スコープ 1 糸川期 & & 166 & JT0 & アク \\
\hline 76 & & & & $167 \mid$ & Jт 0805 & \\
\hline 77 & JT 9002 & 本庄町の家 & & 168 & | Jт 0806 & AOハウス \\
\hline 78 & j7 9005 & CASA ROSSA & 小林克彦 & 169 & Jт 0806 & ICHハウス \\
\hline 79 & 9007 & 磯子 & & 170 & JT 0810 & 杪新 \\
\hline 80 & 9008 & 生田 & & | 171 & JT 0810 & \\
\hline 81 & JT 90 & & & 172 . & | JT 0909 & \\
\hline 82 & Jт 90 & & & 173 . & JT 1001 & MA-HO \\
\hline 83 & JT 9012 & HOUSE OF THR & & 174 . & JT 1002 & CELLUOID JAM \\
\hline 84 & |ЛT 9201 & 南千里の家 & 木原千利 & 175 | & |JT 1004 & 廿日市の家 \\
\hline 85 & JT 9204 & 目神山の家11 & 石井修 & 176 & |JT 1004 _ & \\
\hline 86 & JT 92 & GIOABK & & 177 & JT 1005 & \\
\hline 87 & JT 9206 & 日本橋 & 岸和 & 178 & JT 1006 & 茅ヶ証 \\
\hline 88 & JT 9207 & プールの & & 179 . & |ЈT 1008 & \\
\hline 89 & JT 9208 & BEAN HOUSE & 入江経一 & $180]$ & JT 1011 & 大井松田の住宅 \\
\hline 90 & JT 9209 & 乙金の住宅 & 有馬裕之 & 181 & SK1012 & HOUSE OM \\
\hline & 9211 & 上連雀の家 & アーキテクトファイ & & & \\
\hline
\end{tabular}

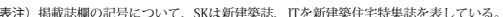


法としている（参考文献 14）。具体的な分析においては、著者ら 4 名 によって資料とした言説から『設計意図』を抽出し、資料総体におけ る個々の意味内容の類似性・背反性を判断し、それらをトポロジカル な関係として図化することで『設計意図』の全体像の把握を試みてい る。またこのようなプロセスにおいて『設計意図』の意味内容に関す る著者らの判断が異なる場合は、相互に意見の一致が得られるまで議 論を行い、最終的に全ての資料についての判断が一致するまで分析を 繰り返している。川喜田二郎は「累積的 KJ 法」としてこのような分 析方法の妥当性を説明している（参考文献 14, pp 111-112）。

注 14)《関連領域》と『設計意図』は基本的にはそれぞれ独立した文章として 抽出できるが、資料によってはそれらがひとつの文章中に複合して現れ ることもある。その場合、ひとつの文章をそれぞれの視点から読み解く ことでその内容を区分し、抽出している。

注 15) 複層\} はそれぞれの屋上庭園の面積が同程度であることを原則とし、 その大小に著しく差がある場合は、面積が大きい方の断面位置に応じ て \{単層 (上)\}、あるいは \{単層 (中) \} に分類している。また、屋 上に出るための塔屋の屋根については除外するものとする。

注 16) 住宅の屋根面が複数層に分かれている事例に関しては、そのうち屋上 庭園と同レベルの屋根面のみに限定して扔り、当該屋根面に扔ける屋 上庭園部分の占める割合から、全体、部分の分類をしている。

注 17) ここでは、屋上庭園をもつ層の住宅平面において、屋上庭園部分の平 面輪郭が住宅全体の平面輪郭の 4 辺に接しているものを「居室を包含 するもの」、3辺に接しているものを「居室と並置するもの」、2辺未 満のものを「居室に包含されるもの」としている。

注 18) 本論では 181 の作品を対象に 229 の設計意図を抽出し資料としてい る。これを構成パタン数で平均すると、ひとつのパタンあたり 38 資 料程度が該当することになる。ここでは、この平均該当資料数、执よ び付表に示す構成パタンと『設計意図』との対応関係を考慮し、全面 型、居室並置型、中庭型の 3 つのパタンについて取り上げている。な 㧍、付表中の括弧内の数字はそれぞれ『設計意図』の大枠の内訳を示 して抢り、左が【活動領域の充足】、右が【空間表現への志向】に該 当する資料数である。

付表 屋上庭園形式の構成パタンと『設計意図』

\begin{tabular}{|c|c|c|c|c|c|c|c|}
\hline & \multicolumn{6}{|c|}{ 『設計意図』 } \\
\hline & & $\begin{array}{l}\text { 景観との調和 } \\
\text { (20/12) }\end{array}$ & $\begin{array}{c}\text { イメージの投影 } \\
55(0 / 55)\end{array}$ & \begin{tabular}{|c|} 
生活空間の搪張 \\
68 (68/32)
\end{tabular} & \begin{tabular}{|c|} 
空間の構成的操作 \\
\end{tabular} & \begin{tabular}{|c|} 
敖地の有効利用 \\
$24(24 / 0)$
\end{tabular} & $\begin{array}{l}\text { 住性能の向上 } \\
40(40 / 0)\end{array}$ \\
\hline \multirow{6}{*}{$\begin{array}{l}\text { 構 } \\
\text { 多 } \\
\text { 帒 }\end{array}$} & 全面型 & $7(5 / 2)$ & $11(0 / 11)$ & $7(7 / 2)$ & $9(2 / 9)$ & $4(4 / 0)$ & $11(11 / 0)$ \\
\hline & 部分型 & $4(2 / 2)$ & $9(0 / 9)$ & $6(6 / 0)$ & $0(0 / 0)$ & $3(3 / 0)$ & $8(8 / 0)$ \\
\hline & 居室包囲型 & $2(2 / 0)$ & $3(0 / 3)$ & $5(5 / 3)$ & $6(3 / 6)$ & $5(5 / 0)$ & $2(2 / 0)$ \\
\hline & 居室並置型 & $11(7 / 4)$ & $11(0 / 11)$ & $27(27 / 17)$ & $26(17 / 26)$ & $8(8 / 0)$ & $10(10 / 0)$ \\
\hline & 中庭型 & $3(2 / 1)$ & $14(0 / 14)$ & $21(21 / 8)$ & $14(8 / 14)$ & $3(3 / 0)$ & $6(6 / 0)$ \\
\hline & 段床型 & $5(2 / 3)$ & $7(0 / 7)$ & $2(2 / 2)$ & $4(2 / 4)$ & $1(1 / 0)$ & $3(3 / 0)$ \\
\hline
\end{tabular}

\section{参考文献}

1) W.Boesiger, O.Stonorov : Le Corbusier Complete Works vol.1 pp.128-129, Les Editions d'architecture, 1964

2) レオナルド・ベネヴオロ 著, 武藤章 訳：近代建築の歴史（下） pp.76-77, 鹿島出版会, 1979

3) ル・コルビュジエ 著, 井田安弘, 芝優子 訳 : プレシジョン (上) pp.70-80, (下) p.9, 鹿島出版会, 1984

4) 横山天心 , 奥山信一, 他 : 屋上庭園をもつ住宅の設計意図 - 建築家 の住宅設計論に関する研究 8 , 日本建築学会大会学術講演梗概集 F-2, pp.499-500, 2002

5）横山天心, 奥山信一, 他：住宅設計論にみられる屋上庭園の領域的広 がり - 建築家の住宅設計論に関する研究 9, 日本建築学会大会学術講 演梗概集 F-2, pp.501-502，2002

6）千代章一郎：ル・コルビュジエの「屋上庭園」における野生性, 日本 建築学会計画系論文集, NO.692 pp.2241-2249, 2013.10

7) 森國洋行, 朽木順鋼, 前田忠直：ラ・ロッシュ/ジャンヌレ邸の平 面・屋上庭園の意味 - ル・コルビュジエの住宅作品における生成過程 の研究 2, 日本建築学会近畿支部研究報告集. 計画系 38, pp.961-964, 1998. 5

8) 江連佳祐, 安森亮雄: 屋上緑化された都市住宅作品の外形構成, 日本 建築学会大会学術講演梗概集 F-2, pp.761-762, 2010

9) 宮崎文子, 寺内美紀子, 千葉友紀 : 屋上緑化可能建築の抽出と構成 屋上緑化可能建築の配置からみた高密度都市に打ける空中緑地の構 成 1, 日本建築学会大会学術講演梗概集 F-2, pp.27-28, 2011

10）宮崎文子, 寺内美紀子, 千葉友紀 : 屋上緑化可能建築の分布と空中緑 地の構成 - 屋上緑化可能建築の配置からみた高密度都市に扔ける空中 緑地の構成 2 , 日本建築学会大会学術講演梗概集 F-2, pp.29-30, 2011

11) 四ヶ所高志, 奥山信一：現代日本の建築家によるコア型平面をもつ 住宅の設計意図と構成形式 - 近代主義建築の空間言語を題材とした 現代建築家の住宅設計論に関する研究, 日本建築学会計画系論文集, NO.670 pp.2291-2298, 2011.10

12) 四ヶ所高志, 奥山信一, 他：現代日本の建築家による一室空間形式 の住宅の設計意図 - 近代主義建築の空間言語を題材とした現代建築 家の住宅設計論に関する研究, 日本建築学会計画系論文集, NO.677 pp.1617-1624, 2012.7

13) 四ヶ所高志, 奥山信一, 他 : 現代日本の建築家によるピロティ形式の 住宅の設計意図, 日本建築学会計画系論文集，NO.684 pp.355-364, 2013.2

14) 川喜田二郎：発想法, 中央公論社, 1967 


\title{
DESIGN THEME IN HOUSES WITH ROOF GARDEN \\ BY CONTEMPORARY JAPANESE ARCHITECTS
}

\section{Takashi SHIKASHO*, Tenshin YOKOYAMA**, Taishin SHIOZAKI*** and Shin-ichi OKUYAMA ${ }^{* * * * *}$}

\author{
* Assist. Prof., Dept. of Architecture, Fukuoka University, Dr.Eng. \\ ** Assoc. Prof., Faculty of Art and Design, University of Toyama, Dr.Eng. \\ *** Assist. Prof., Dept. of Architecture and Building Engineering, Tokyo Tech., Dr.Eng. \\ **** Prof., Dept. of Architecture and Building Engineering, Tokyo Tech., Dr.Eng.
}

The roof garden, a paved or planted open terrace on the roof of building, is one of the most characteristic modernist spatial types, as recognized by Le Corbusier's "the Five Points of a new architecture". According to his statement, the roof garden is "conquered land (le sol conquis)" by reinforced concrete flat slab, whereas the pilotis, the other one of "the Five Points", is "liberated land (le sol libéré)" on the ground. Le Corbusier realized many roof garden models in his works, as exemplified in "Villa Savoye (1928-31)". After World War II, many Japanese architects have took notice on spatial uniqueness of the roof garden model to compose interior and exterior space at once, and then a number of such houses particularly made their appearance in Japan. From this point, this report aims to illustrate and examine how Japanese architects of the time extrapolated a design theme from this model, based on a study of both text and actual composition of such work as it appeared in architectural publications.

Initially, two aspects of the roof garden concept were extracted from the explanatory text by architect themselves (Fig. 1), and each scheme was then subjected to a "KJ-method" analysis (originated by KAWAKITA Jiro). First, the architect's intentions in adopting a roof garden scheme were scrutinized, and secondly, each architect's distinct view of the spatial character on roof garden was assessed. The intentions were classified into 6 categories; [Harmonization with the Surroundings], [Projection of Architect's Subjective Image], [Expansion of Living Space], [Rhetoric Operation of Spatial Composition], [Utilization of the Building Site], [Improvement of Living Efficiency] (Fig. 2). The view of the spatial character were divided into 4 classes, regarding with the relation between roof garden and Interior/exterior space; Relating with <Interior Space Only $>$, <both Interior and Exterior Space $>,<$ Exterior Space Only $>,<$ No Relation $>$ (Fig. 3). Then the correspondancy of these two aspects were clarified. The intention of [Expansion of Living Space] and [Rhetoric of Spatial Composition] is corresponding with <Interior Space Only> respectively, and both of them are corresponding with <both Interior and Exterior Space> simultaneously.

At this point, the actual composition of each house was correlated with regard to two aspects involving relationship between Interior and exterior space, namely vertical and horizontal positioning of roof garden. Considering this 2 aspects of the actual composition, each house was classified in 6 types; Full Roof Type, Partial Roof Type, Including Room Type, Juxtaposing with Room Type, Courtyard Type, Stepping Roof Type (Fig. 4).

Finally, the mediation between each architect's thinking and the final composition has been plotted in terms of this dual classification (Fig. 5). As a result, the high relations in architect's thinking (between architect's intention and distinct view of the spatial character) were found, that is, relation between [Improvement of Living Efficiency] and <Exterior Space Only>, and between both [Expansion of Living Space], [Rhetoric Operation of Spatial Composition] and <both Interior and Exterior Space>. Furthermore, in the former case architect's thinking tend to be subject to the Full Roof Type, and in the latter case subject to the Juxtaposing with Room Type. From the above, the framework of the design theme on houses with roof garden by contemporary Japanese architects was established. 